\title{
CHALLENGES AND BENEFITS OF USING ELEARNING DURING COVID-19 A CASE STUDY OF LECTURERS OF ZAWIA UNIVERSITY, LIBYA
}

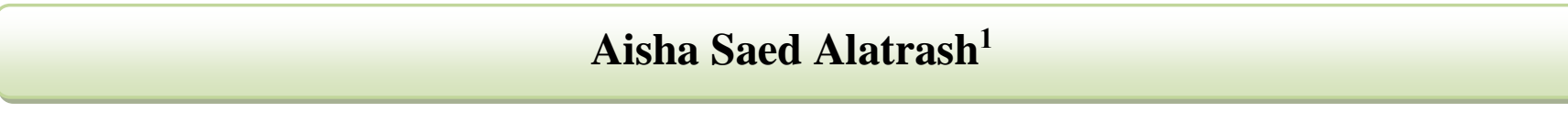

${ }^{1}$ Zawia University - Faculty of Education-Agelat

Email: a.alatrash@zu.edu.ly

HNSJ, 2021, 2(9); https://doi.org/10.53796/hnsj2933

\section{Published at 01/09/2021}

\section{Accepted at 26/08/2021}

\begin{abstract}
In developing countries like Libya, the implementation of eLearning into the education system in the universities would face many challenges related to infrastructure, finance, ability, proficiency, and lecturers and students skills. Yet, it would be a good chance to improve teachers and students expertise in terms of using new technologies-based systems. Besides, it would raise the quality of the teaching system in the universities in addition to solve the issue of study interruption resulted from interior wars, coronavirus, etc. Thus, the aim of this study was to investigate the experience of using eLearning at one of the Libyan universities, Zawia University. Consequently, identifying lecturers' attitudes towards eLearning, discovering the potential challenges obstacle applying it, and realising the chance of including it as a part of the higher education system. The methodology used in this study was an online questionnaire, which targeted the teaching staff of Zawia University. 80 responses were received and the collected data analysed by using SPSS. The study concluded that although there is technical abilities existence for using eLearning, there are some difficulties decrease the quality and provision of it. In the end, some recommendations were suggested in order to enhance the implementation of eLearning as a part of the teaching system in Libyan universities, along with some suggested future studies.
\end{abstract}

Key Words: eLearning, Zawia University, lecturers, teaching staff, challenges, benefits. 


\section{دراسة تمديات ومنـافع استفدام التعليم الإلكتروني خلال كمفيد-19 دراسة حالة أعضاء هيئة التدريس بجامعة الزاوية، ليبيا}

\section{عائشة سعيد الأطرش 1}

\section{1 عضو هيئة تدريس في قسم الحاسوب، جامعة الزاوية ـ كلية التربية العجيلات}

بريد الكتروني: a.alatrash@zu.edu.ly

HNSJ, 2021, 2(9); https://doi.org/10.53796/hnsj2933

تاريخ القبول: 2021/08/26م

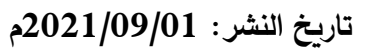

المستخلص

في البلدان النامية مثل ليبيا، سيواجه تطبيق التعليم الإكتروني في نظام التدريس الجامعي العديد من التحديات المتعلقة بالبنية التحتية، والتمويل، والقدرة، والكفاءة، ومهارات المحاضرين والطلاب، ومع ذلك، ستكون فرصة جيدة لتحسين خبرة المحاضرين والطلاب من حيث استخدام الأنظمة القائمة على التقنيات الحديثة، إلى جانب ذلك سترفع من كفاءة وجودة نظام التدريس في الجامعات، بالإضافة إلى حل مشكلة انقطاع الدراسة الناتج على سبيل المثال عن الحروب الداخلية وجائحة كورونا وإلى غير ذلك، وبالتالي كان الهدف من هذا البحث هو دراسة تجربة استخدام التعليم الإكتروني في أحد الجامعات الليبية وهي جامعة الزاوية، وبالتالي التعريف بإتجاهات أعضاء هيئة التدريس نحو استخدام التعليم الإكتروني واكتثاف التحديات التي تعرقل تطبيقه، وإدراك فرصة تضمينه كجزء من نظام التدري في التعليم العالي، كانت أداة البحث المستخدمة في هذه الدراسة عبارة عن استبيان الإكتروني استهدف أعضاء هيئة التدريس بجامعة الزاوية، حيث تم استلام عدد 80 من الردود تم تحليل بياناتهم باستخدام برنامج الحزمة الإحصائية للعلوم الاجتماعية، استتتج الدراسة بأنه على الرغم من وجود قدرات تقنية لاستخدام التعليم الإكتروني إلا أن هناك بعض الصعوبات التي تقلل من كفاءته وامكانية توفيره، في نهاية البحث تم اقتراح بعض التوصيات من أجل تعزيز تنفيذ التعليم الإكتروني كجزء من نظام التدريس في الجامعات الليبية، إلى جانب بعض الدراسات المستقبلية المقترحة. الكلمات المفتاحية: التعليم الإلكتروني، جامعة الزاوية، المحاضرون، أعضاء هيئة التدريس، التحديات، المنافع. 


\section{Introduction}

Despite the massive spreading of coronavirus worldwide, many countries have applied restrictive measures recommended by the World Health Organisation (WHO) including decrease gathering and creations of crowds in order to reduce the infection. Consequently, varieties of governmental and private organisations have had to reduce their staff or close entirely. Besides, educational institutions have been also affected and have had to lessen their classrooms or close them completely. If this closure is extended and continued for a too long time and alternative options such as distance education are not applied, there will be a possibility of loss of educational opportunity and, therefore, threaten the economy of the countries (European Data Portal 2020; Azzi-Huck and Shmis 2020). Thus, to decrease the risk of the closure, it was important to move towards distance learning to continue provision of education for students.

E-learning is one of the essential aspects of distance learning (Rosenberg, 2001) that has obtained great attention for many years and used as an important learning tool in many countries (Hameed et al. 2008). In addition, the increasing growth of information and communication technologies and the good quality and speed of internet help increasing efficiency and effectivity of eLearning (Hameed et al. 2008; Akkoyuklu and Soylu 2006; Rossen and Hartley 2001).

Although eLearning has gained popularity in many countries for years (Li and Lalani, 2020), it is still not accepted or accredited in other countries where the learning system is only based on the traditional learning mechanism (Akbar, 2005). Subsequently, applying eLearning in these countries during the crisis of coronavirus might face many challenges, including infrastructure and financial difficulties in addition to the lack of teachers and students' experiences and skills as well as the absence of internet and communication facilities.

Libya, like other countries, has been facing coronavirus that caused the partial and complete closure of educational institutions, including universities. Consequently, marketing for eLearning, specifically in universities, has started.

The University of Zawia is one of the Libyan universities that experienced using eLearning. It started marketing for eLearning in March 2020 as a procedure to complete an existing traditional education interrupted by coronavirus. Although this experience was short and limited as a few of the teaching staff and some students participated in, it could be the start and the first step towards online education. Therefore, this paper aims to study the lecturers' reactions and views about using eLearning. Furthermore, it investigates challenges they faced and benefits they gained, and discover the chance of adopting eLearning at Zawia University in the future.

Firstly, this study focuses on the background and concept of eLearning along with its advantages, disadvantages, and challenges discussed in previous papers. Secondly, the summary of the experiences of eLearning in the University of Zawia is demonstrated. Then, the research methodology is clarified. Finally, the result of this study is illustrated and discussed; accordingly, the conclusion is presented along with some recommendations suggested by the researcher.

\section{Research questions}

1- What are the lectures' attitudes of Zawia University towards eLearning?

2- What were the eLearning challenges faced by lecturers of Zawia University? 
3- Does the teaching staff of Zawia University agree with the benefit of eLearning?

\section{The important of the study}

In addition to the interior war in Libya, which often affects the education of some cities, Libya has also been affected by coronavirus, which causes the closure of educational institutions including universities. Moreover, education must improve to meet today's needs and students must be sufficiently educated even in hard circumstances. Consequently, a key element for achieving that and overcoming the mentioned issues and therefore, increasing the quality of educational institutions is to encourage the adoption of eLearning.

Furthermore, the increase of technological and scientific development and most universities all over the world are importantly taking into consideration using information and communication technologies including eLearning. That could notably clarify the importance of adopting eLearning in Libyan universities.

This study would be beneficial in developing the strategy of including eLearning at Zawia University and other Libyan universities as well.

\section{Research objectives}

The research objectives are:

1- To identify the lecturers experience of using eLearning at Zawia University.

2- To illustrate lecturers' attitudes towards eLearning.

3- To investigate the eLearning challenges were faced by lecturers.

4- To discover the benefit of using eLearning from lecturers' prospect.

5- To conclude opportunity of including eLearning as a part of the teaching system at Zawia University.

\section{Research limitation}

The limitation of this study is that the respondents of the questionnaire was few compared to the number of the teaching staff of Zawia University, which is about 2056 (University of Zawia Website, 2021), while the research participants were only 80 and that somewhat minimises the generality of the result. Additionally, the experience of eLearning at Zawia University was short and limited and that might affect the answer of the participants of the study in some cases.

\section{Literature Review}

As eLearning has been increasingly used as a part of the education system in various countries, many studies have been conducted and discussed different topics about it. These topics included chances, challenges, importance, and difficulties of eLearning in different countries, circumstances, times, and cases. Notwithstanding, This research focused on the experience of using eLearning in one of the Libyan universities, Zawia University. It discovered challenges, benefit and opportunity of eLearning according to lecturers' opinions during this experience with taking into consideration some related eLearning topics discussed in previous studies such as advantages, disadvantages and challenges.

\section{E learning background and concept}

The development of computer, smart devices and networking technologies are offering different facilities to support learning in a simple and flexible way (Zhang et al. 2004). 
E learning is one of the critical learning tools that emerged with the advancement of information and communication technology and has been spreading rapidly (Akkoyuklu and Soylu 2006; Alruwais et al. 2018).

E learning, which is also known as online-distance learning, hybrid learning (Arkorful and Abaidoo, 2015), electronic learning, online learning, and web-based learning, is technology-based learning (Khan, 2005). It depends mainly on the internet and communication technologies to deliver educational content for students and outside of traditional classrooms, this content can be accessed anytime and anywhere (Bates and Bates, 2005). In addition, eLearning is defined as delivering educational content through digital devices such as computers and smart phones with an internet connection (Clark and Mayer, 2016). It is also defined as the utilizing of information and communication technologies to access online learning resources (Arkorful and Abaidoo, 2015). Moreover, it is claimed that the advancement of communication technology, especially the internet, transformed distance learning to eLearning (Liu and Wang, 2009).

Moreover, eLearning enables students to attend lectures and contact lecturers online (Elkins and Pinder, 2015) via an educational environment created and supported by virtual classrooms, emails, video calls, voice calls, short messages, etc. (Holmes and Gardner, 2006). In addition, homework and assignments can be simply conducted online (Ibid). Furthermore, the significant advance of the technology and application development of eLearning facilitates doing electronic assessment and exams (Alruwais et al. 2018). Moreover, electronic learning is beneficial for students who cannot attend actual lectures (Singh, 2001).

\section{E-learning advantage and disadvantage}

E learning like other learning tools has advantages, disadvantages, and difficulties, some of which are represented below.

\section{E-learning advantages/benefits}

E learning has many advantages for educational organisations, lecturers and students. These advantages make it an important facility to improve the education and increase the quality of it, therefore, illuminating the budget investing on it. These advantages can be summarised as follows:

E learning enables students to easily communicate and interchange opinions and ideas with each other and with their lecturers, as it eliminates potential barriers such as fears of talking to others (Arkorful and Abaidoo 2015; Hsbollah and Idris 2009).

Moreover, the most previews studies indicate the effectiveness of eLearning in developing both lecturers and students experiences as it helps students and lecturers to develop their knowledge about using computer programs and the internet, consequently, that will help them throughout their careers (Nedeva and Dimova, 2010). Besides, the most successful educational organisations in the world have distinguished the role of eLearning in transforming skills and performance (Arkorful and Abaidoo, 2015).

There is also the advantage that eLearning encourages self-learning, as each student is able to display e lectures and study them at their own pace and speed (Arkorful and Abaidoo 2015; Hsbollah and Idris 2009). Besides, it improves the quality of the teaching and learning process (Hsbollah and Idris, 2009), and organisational 
performance because of easing the access to learning materials and services (Arkorful and Abaidoo 2015; Holmes and Gardner 2006).

One more advantage is flexible attendance of lectures, as they are available when and where they are needed (Hameed et al. 2008; Nedeva and Dimova 2010; Elkins and Pinder 2015). Therefore, it raises the convenience of learners as they can access lessons at any time from any place (Rosenberg 2001; Klein and Ware 2003; Welsh 2003; Holmes and Gardner 2006; Arkorful and Abaidoo 2015). Besides, as a new lesson is built on the previous ones, electronic lectures enable students to effortlessly review the previously educated lessons (Nedeva and Dimova 2010; Elkins and Pinder 2015).

Furthermore, virtual classrooms are not constrained and more capacity are available than the traditional classrooms so many learners can attend and be learned in less time (Welsh, 2003). Likewise, eLearning increases the chance of registration and allows students from different places and faraway cities to register as eLearning eliminates the geographical obstacles (Elkins and Pinder, 2015). Meanwhile, eLearning could solve the problem of lecturers shortage (Mackey, 2012), as a number of students attending online lecture could be much more than students who attend lecture in an traditional classroom.

In addition, eLearning costs less in terms of that there is no need to travel for giving and attending lectures, as well as, no more buildings is required in case of massive numbers of students (Rosenberg 2001; Rossen and Hartley 2001; Arkorful and Abaidoo 2015; Hameed et al.2008).

What is more, eLearning allows easily contacting with references throughout websites, databases, and e-libraries (Holmes and Gardner, 2006). It also facilitates quick assessment, electronic correction, and immediate results throughout e-assessment systems (Gilbert et al. 2011 cited at Alruwais et al. 2018). In addition to that electronic lectures can be accessed, updated, and reused easily and effortlessly as many times as required (Rosenberg, 2001). Last and not least, eLearning simplifies collaboration between universities and research centres (Rossen and Hartley, 2001).

\section{E-learning disadvantage}

On the other hand, there are disadvantages of eLearning, some of which mentioned below:

First, there is no actual interaction between lecturers and students (Akkoyuklu and Soylu 2006; Elkins and Pinder 2015). Therefore, learners lack communication skills so they may acquire sufficient academic knowledge through eLearning but they might not possess the required skills to deliver the gained knowledge to others (Arkorful and Abaidoo 2015; Hsbollah and Idris 2009; Hameed et al. 2008).

Additionally, E learning could be costly, as it depends on computers and/or smart devices and needs a good quality and speed internet (Arkorful and Abaidoo, 2015). Besides, more effort is needed from lecturer to prepare e lectures compared with faceto-face lectures (Ibid).

Another important drawback is that eLearning cannot be used effectively in all study fields and it is appropriate for humanities and social fields instead of scientific fields, which require hands-on practical experiences (Tamm 2019; Arkorful and Abaidoo 2015; Hsbollah and Idris 2009). For instance, it is difficult to develop practical skills, such as chemical experiments, a dissection in scientific and medical specialisation or 
practical training in engineering and industrial specialisation, online (Tamm, 2019). One more downside of eLearning is the high possibility of plagiarism and cheating during online assessments (Hsbollah and Idris 2009; Rowe 2004; Heberling 2002; Kennedy et al. 2000). It is complicated to monitor students and detect cheating during online exams as students taking them from their own environments and devices (Tamm, 2019). Besides, it is difficult to verify the identity of students taking online exams without using authentication systems and that might result in taking online exam by a third party instead of students (Ibid).

\section{Challenges of eLearning}

E learning is one of the important and successful technology all over the world in case of existing the requirements it needs. Additionally, although the advantages of eLearning may give the impression that delivering electronic lectures are pretty simple and effortless, there is a number of challenges needs to be dealt with. This section illustrates below some possible challenges discussed in previous papers: -

Firstly, the cost perspective is a critical challenge (Hameed et al. 2008) facing teachers and learners. It has been cited that there is a financial difficulty to participate in eLearning, as its required facilities are costly for them (Rena, 2008). Likewise, computers and smart devices are not affordable for all (Elkins and Pinder, 2015), as well as, the essential eLearning facilities, such as a good and free internet connection, were not provided (Li and Lalani, 2020).

Secondly, most teachers and students lack sufficient skills and experience in using information and communication technology (Elkins and Pinder, 2015). Besides, the weakness of the English language of some lecturers and students could be another challenge, as most of the programs and applications are in English.

Another critical challenge is the low quality and speed of the internet which does not enable displaying learning materials such as recorded lectures, video (Elkins and Pinder, 2015), in addition to the continuous interruption of electricity and the internet connection. Moreover, the internet is often hard to access, especially, in rural area and usually inferior or not available at the times needed (Montoya and Barbosa, 2020). It is also argued that even with the advancing growth of digital technology, the rates of computer and internet illiterate people are not few (Teltscher, 2020), hence, eLearning as an educational method cannot be reachable to most people.

Finally, there are administrative challenges that impede development and make procedures inflexible as eLearning is facing a struggle with accreditation (Hameed et al. 2008). Consequently, eLearning is not considered as authentic and effective as traditional learning and that declines its legitimacy.

\section{Zawia University and eLearning experience during coronavirus pandemic}

Zawia University is one of the important Libyan universities located in Zawia. It has many faculties located in three cities (Zawia, Agelat and Zwara), and teach variety of specialisations of humanity, applicable and medical sciences (University of Zawia Website, 2021). It was one of the first universities to use eLearning as a solution to the closure of universities because of Covid-19.

The university had to find a way to cover as much of the curriculum as possible using the right choice of eLearning facilities which could be simple, possible and accessible for untrained students and lecturers. Firstly, the university established an eLearning centre, which tried to suggest and provide good arrangement and instructions for using 
some eLearning facilities. The eLearning centre created a supporting team on Telegram, which has provided basic different services such as advices and programs for the teaching staff. Additionally, in order to improve the lecturers' skills, the eLearning centre conducted actual and online training courses on Google Classrooms and Google Meet.

Moreover, the eLearning centre suggested some platforms for lecturers to create their lectures and communicate with students including Microsoft PowerPoint 2016 and Screen recorder programs to register lectures, and Pdf files to share a copy of lectures contents, as well as, Google Suite to upload and share lectures, and interact with students. In addition, some other social media tools such as Viber, Messenger and Telegram were used to communicate with students.

Although the University of Zawia has an official website, a virtual learning environment has not been established yet.

\section{Research Methodology}

The main goal of this study is to investigate the prospects of the lecturers of Zawia University towards eLearning and its benefits, and discover challenges they faced during their experience. Consequently, the methodology of this study depended on collecting the lecturers' attitudes towards online teaching.

\section{- Data Collection Method}

The data collection method was an online close-ended questionnaire. This method was chosen because respondents would have enough time to reply conveniently, as well as, this method saves time as the gathered data can be analysed easily, fast and accurately. Additionally, more participates can be reached fast and easily as it eliminates the barriers of distances.

\section{- Data Collection tool}

A questionnaire was used to collect the study data, and included statements corresponding to the three research questions. Additionally, the questionnaire was created by the Google Forms application and the link of it was sent to the social media groups of faculties of Zawia University. The purpose of the study was clarified at the beginning of the questionnaire. The email addresses were neither required nor collected in order to respect anonymity and confidentially.

Furthermore, the questionnaire consisted of a group of questions divided into four sections. The first section gathered the participants demographics including age, gender, specialisations and years of experience. It also asks whether a participant has used eLearning or not in order to highlight the significant challenges that prevent using it.

Additionally, for answering the first research question, the second section of the questionnaire consisted of 5 statements of five-point Likert Scale asks lecturers to rate their opinion from 1(strongly disagree) to 5 (strongly agree) about eLearning usage at universities. The third section, which was used to answer the second study question, contained 16 statements of 3-point Likert Scale. This section asks about the possible challenges that might affect eLearning usage. Finally, to answer the third research question, the last section of the questionnaire, which contained 5 statements of fivepoint Likert Scale, investigated participates' point of view about the possible benefit of 
using eLearning. In general, all the statements included in the last three sections of the questionnaire developed through the literature review.

\section{- Reliability of the Questionnaire}

The internal consistency of the questionnaire was measured by finding Cronbach Alpha for each section using SPSS (Statistical Package for the Social Sciences). As presented in table 1 below, the values of Cronbach's Alpha for the 3 sections were $0.89,0.81$ and 0.83 , which indicated a high level of reliability to conduct the study.

Table 1: the result of the reliability test of the questionnaire

\begin{tabular}{|l|l|l|}
\hline Section & Number of Items & Cronbach Alpha Value \\
\hline Lecturers' attitude about eLearning & 5 & 0.89 \\
\hline Challenges lecturers faced & 16 & 0.81 \\
\hline Benefits of eLearning & 5 & 0.83 \\
\hline
\end{tabular}

\section{- Research participates}

The population of the study targeted lecturers of Zawia University, who have used eLearning or not yet. Nevertheless, only 80 lecturers, differing in age, gender, specialisation, and years of experience, contributed to this study and filled the questionnaire. The data was collected from participants by electronic questionnaire. The following table shows a detailed description of the study sample.

Table 2: Description of the study sample

\begin{tabular}{|c|c|c|c|}
\hline \multicolumn{4}{|c|}{ Participants Demographic } \\
\hline Variables & Category & Count & Percentage \\
\hline Gender & $\begin{array}{l}\text { Male } \\
\text { Female }\end{array}$ & $\begin{array}{l}31 \\
49\end{array}$ & $\begin{array}{l}38.8 \% \\
61.3 \%\end{array}$ \\
\hline Age & $\begin{array}{l}\text { Less than } 30 \\
30-39 \\
40-49 \\
50 \text { and more }\end{array}$ & $\begin{array}{l}2 \\
23 \\
40 \\
15\end{array}$ & $\begin{array}{l}2.5 \% \\
28.7 \% \\
50 \% \\
18.8 \%\end{array}$ \\
\hline Specialisation & $\begin{array}{l}\text { Applied science } \\
\text { Humanities science } \\
\text { Medical science }\end{array}$ & $\begin{array}{l}29 \\
46 \\
5\end{array}$ & $\begin{array}{l}36.3 \% \\
57.5 \% \\
6.2 \%\end{array}$ \\
\hline $\begin{array}{l}\text { Years of } \\
\text { Experience }\end{array}$ & $\begin{array}{l}\text { Less than } 6 \text { years } \\
6-10 \text { years } \\
11-15 \text { year } \\
\text { More than } 15\end{array}$ & $\begin{array}{l}13 \\
29 \\
16 \\
22\end{array}$ & $\begin{array}{l}16.3 \% \\
36.3 \% \\
20 \% \\
27.5 \% \\
\end{array}$ \\
\hline $\begin{array}{l}\text { Have you used } \\
\text { eLearning? }\end{array}$ & $\begin{array}{l}\text { Yes } \\
\text { No }\end{array}$ & $\begin{array}{l}57 \\
23\end{array}$ & $\begin{array}{l}71.3 \% \\
28.7 \%\end{array}$ \\
\hline
\end{tabular}

As shown in table 2, out of 80 respondents, 31 (38.8\%) are male and $49(61.3 \%)$ are female. According to the age, 2(2.5\%) are less than 30, 23(28.7\%) are between 30 and $39,40(50 \%)$ are between 40 and 49 , and $15(18.8 \%)$ are 50 and above. Additionally, most of the respondents $(46,57.5 \%)$ with a specialisation in humanities science, some of them $(29,36.3 \%)$ with a specialisation in applied science, and just $5(6.2 \%)$ with a specialisation in medical science. Furthermore, 13(16.3\%) of respondents have an experience less than 6 years, 29(36.3) have an experience between 6 and 10 years, $16(20 \%)$ have an experience between 11 and 15 years, and 22(27.5\%) have an experience more than 15 years. Finally, 57(71.3\%) of respondents have used eLearning, whereas 23(28.7\%) have not used it. 
To summarise, the simple of the study included participants from both genders, from different age groups, from diverse specialisations, and with different years of experience. As a result, the differentiation of the questionnaire participants were enough to conduct the study and answer the research questions.

\section{- Data analysis}

The data were analysed using SPSS (Statistical Package for the Social Sciences). Firstly, the following five-point Likert scale was used in the first and third dimensions of this study: 1: Strongly Disagree (SDA), 2: Disagree (DA), 3: Neutral (N), 4: Agree (A) and 5: Strongly Agree (SA). Additionally, the following three-point Likert scale was used in the second dimension: 1: No, 2: Maybe and 3: Yes. Then, the means and Standard Deviation for each statement in the three dimensions were calculated and, subsequently, the average of each dimension was calculated used the formula below in order to find the general tendency of participants for each dimension:

\section{Finding and Discussion}

$$
\text { Average }=\frac{\text { Mean }}{\text { Number of Items }}
$$

\section{- Lecturers' attitude towards using eLearning}

For answering the first research question, which is "What are the lectures' attitudes of Zawia University towards eLearning?", means and standard deviation were calculated for each statement of the third section of the questionnaire and the result is demonstrated in the table below. After that, the average of the means was also calculated and compared to the 5-point Likert scale.

Table 3: Items statistics for lecturers' attitude towards eLearning usage

\begin{tabular}{|c|c|c|c|c|c|c|c|c|c|c|}
\hline & Statement & SDA & DA & $\mathbf{N}$ & $\mathbf{A}$ & SA & Means & St.D & $\begin{array}{l}\text { per } \\
\%\end{array}$ & $\begin{array}{l}\text { General } \\
\text { Tendency }\end{array}$ \\
\hline 1 & $\begin{array}{l}\text { eLearning is the best solution for } \\
\text { education continuity during crises } \\
\text { such as Coronavirus }\end{array}$ & 3 & 4 & 8 & 39 & 26 & 4.013 & 0.9872 & 80.25 & A \\
\hline 2 & $\begin{array}{l}\text { eLearning can become a part of } \\
\text { learning process in case a lecturer } \\
\text { or a student cannot attend a } \\
\text { classroom }\end{array}$ & 0 & 6 & 6 & 45 & 23 & 4.063 & 0.8167 & 81.25 & $\mathbf{A}$ \\
\hline 3 & $\begin{array}{l}\text { Combining eLearning with } \\
\text { traditional education can increase } \\
\text { the quality of learning process and } \\
\text { efficiency of lecturers and } \\
\text { students }\end{array}$ & 0 & 3 & 5 & 40 & 32 & 4.263 & 0.7419 & 85.25 & $\mathbf{A}$ \\
\hline 4 & $\begin{array}{l}\text { Students can gain sufficient } \\
\text { knowledge and required } \\
\text { experience during finishing all } \\
\text { their courses online }\end{array}$ & 3 & 22 & 12 & 26 & 17 & 3.4 & 1.2076 & 68 & $\mathbf{N}$ \\
\hline 5 & $\begin{array}{l}\text { eLearning might replace } \\
\text { traditional education in the future } \\
\text { in case the required facilities } \\
\text { provided }\end{array}$ & 1 & 19 & 8 & 38 & 14 & 3.563 & 1.0773 & 71.25 & $\mathbf{A}$ \\
\hline
\end{tabular}


As shown in table 3, the majority of the participants of the study agreed about the statements 1, 2, 3 and 5 with the percentages of $80.25 \%, 81.25 \%$, $85.25 \%$ and $71.25 \%$ respectively. While the averaged responses were neutral about the statement 4 . In addition, as the sum of the means was 19.302 and the number of the items was 5 , therefore the average for this dimension was 3.86. This is closer to the number 4 on the five-Likert scale. Accordingly, it can be said that most of the lecturers have a positive attitude towards eLearning usage.

- eLearning challenges were faced by lecturers

For answering the second research question, which is "What were the eLearning challenges faced by lecturers of Zawia University?", means and standard deviation were calculated for each statement of the third section of the questionnaire and the result is demonstrated in the table below.

Table 4: Means and Standard Deviation for potential eLearning challenges

\begin{tabular}{|c|c|c|c|c|c|c|c|c|}
\hline No. & Challenge & No & Maybe & Yes & Means & St.D & per $\%$ & $\begin{array}{l}\text { General } \\
\text { Tendency }\end{array}$ \\
\hline 1 & $\begin{array}{l}\text { No enough experience about } \\
\text { using eLearning facilities }\end{array}$ & 21 & 30 & 29 & 2.1 & 0.7892 & 70 & Maybe \\
\hline 2 & $\begin{array}{l}\text { The lack of training to } \\
\text { enhance the lecturers' skills } \\
\text { of using eLearning facilities } \\
\text { or using new technologies }\end{array}$ & 19 & 22 & 39 & 2.25 & 0.8191 & 75 & Maybe \\
\hline 3 & $\begin{array}{l}\text { The difficulty of using } \\
\text { eLearning applications in } \\
\text { English }\end{array}$ & 40 & 15 & 25 & 1.8125 & 0.8872 & 60.42 & Maybe \\
\hline 4 & $\begin{array}{l}\text { Absence of privacy and } \\
\text { security during using } \\
\text { eLearning platforms }\end{array}$ & 27 & 35 & 18 & 1.8875 & 0.7462 & 62.92 & Maybe \\
\hline 5 & $\begin{array}{l}\text { The interruption of the } \\
\text { internet connection because } \\
\text { of bad internet services } \\
\text { and/or electricity } \\
\text { interruption }\end{array}$ & 3 & 7 & 70 & 2.8375 & 0.4623 & 94.58 & Yes \\
\hline 6 & $\begin{array}{l}\text { There is no an acceptance of } \\
\text { moving towards eLearning }\end{array}$ & 8 & 38 & 34 & 2.325 & 0.6517 & 77.5 & Maybe \\
\hline 7 & $\begin{array}{l}\text { The lack of direct } \\
\text { interaction between } \\
\text { lecturers and students }\end{array}$ & 8 & 34 & 38 & 2.375 & 0.6632 & 79.17 & Yes \\
\hline 8 & $\begin{array}{l}\text { Disability of using printing } \\
\text { and recording programs to } \\
\text { prepare electronic lectures }\end{array}$ & 48 & 15 & 17 & 1.6125 & 0.819 & 53.75 & No \\
\hline 9 & $\begin{array}{l}\text { There is no willingness to } \\
\text { record lectures vocally }\end{array}$ & 41 & 19 & 20 & 1.7375 & 0.8381 & 57.92 & Maybe \\
\hline 10 & $\begin{array}{l}\text { The deficiency of sufficient } \\
\text { technical skills to create } \\
\text { lectures with high quality } \\
\text { and effective content }\end{array}$ & 31 & 25 & 24 & 1.9125 & 0.8297 & 63.75 & Maybe \\
\hline 11 & $\begin{array}{l}\text { There is no time for } \\
\text { preparing lectures and } \\
\text { interact online with students }\end{array}$ & 17 & 31 & 32 & 2.1875 & 0.7646 & 72.92 & Maybe \\
\hline 12 & $\begin{array}{l}\text { There is no rewards to } \\
\text { motivate lecturers to use } \\
\text { eLearning or even to train } \\
\text { for it }\end{array}$ & 7 & 17 & 56 & 2.6125 & 0.6462 & 87.08 & Yes \\
\hline
\end{tabular}




\begin{tabular}{|l|l|l|l|l|l|l|l|l|}
\cline { 2 - 9 } & $\begin{array}{l}\text { Disability of affording a } \\
\text { high cost of the internet and } \\
\text { free internet access is not } \\
\text { offered }\end{array}$ & 7 & 15 & 58 & 2.6375 & 0.6413 & 87.92 & Yes \\
\hline 14 & $\begin{array}{l}\text { I do not own a computer to } \\
\text { print and record lectures }\end{array}$ & 50 & 13 & 17 & 1.5875 & 0.8221 & 52.92 & No \\
\hline 15 & $\begin{array}{l}\text { Disability of controlling } \\
\text { possible cheating during } \\
\text { assessing students online }\end{array}$ & 7 & 24 & 49 & 2.525 & 0.6556 & 84.17 & Yes \\
\hline 16 & $\begin{array}{l}\text { Difficulty of teaching some } \\
\text { modules that require hand- } \\
\text { on experience }\end{array}$ & 3 & 28 & 49 & 2.575 & 0.5687 & 85.83 & Yes \\
\hline
\end{tabular}

As demonstrated in table 4, it seems that the majority of the participated lecturers faced the challenge of bad internet services and electricity interruption with the highest percentage of $94.58 \%$ of participants' agreement. Additional important challenges, which also got high percentages (between $84.17 \%$ and $87.92 \%$ ) of participants' agreement, are the difficulty of affording a high cost of the internet, the lack of rewards and motivation for using eLearning, the difficulty of teaching some modules that require handon experience, and disability of controlling cheating during online assessments. Another more challenge was the lack of direct interaction between lecturers and students, which seems to be not as significant as the previous challenges.

However, the majority of the participated lecturers did not face either the difficulty of using printing and recording programs to prepare electronic lectures or the disability of owning a computer to print and record lectures.

Finally, many participants were uncertain about the rest of the challenges summarised in: the unavailability of enough eLearning experience, the lack of training, the English language difficulty, absence of privacy and security, rejection of using eLearning, unwillingness to record lectures vocally, the deficiency of sufficient technical skills and unavailability of time for eLearning requirements. As a result, there is a differentiation in the responses for each challenge and that needs to be investigated in further study to identify the possible factors of this differentiation.

- Benefits of using eLearning

For answering the third research question, which is "Does the teaching staff of Zawia University agree with the benefit of eLearning?", means and standard deviation were calculated for each statement of the third section of the questionnaire and the result is demonstrated in the table below. Then, the average of the means was calculated and compared to the 5-point Likert scale. 
Table 5: Items statistics for eLearning Benefit

\begin{tabular}{|l|l|l|l|l|l|l|l|l|l|l|}
\hline & Statement & SDA & DA & N & A & SA & Means & St.D & per \% & $\begin{array}{l}\text { General } \\
\text { Tendency }\end{array}$ \\
\hline 1 & $\begin{array}{l}\text { eLearning increases the } \\
\text { familiarity of technology and } \\
\text { internet }\end{array}$ & 0 & 1 & 0 & 33 & 46 & 4.55 & 0.5715 & 91 & SA \\
\hline $\begin{array}{l}\text { eLearning rises the knowledge } \\
\text { of th importance of } \\
\text { technology in education }\end{array}$ & 0 & 1 & 2 & 38 & 39 & 4.438 & 0.613 & 88.75 & SA \\
3 & $\begin{array}{l}\text { eLearning develops the ability } \\
\text { of self-study }\end{array}$ & 0 & 2 & 3 & 35 & 40 & 4.413 & 0.6879 & 88.25 & SA \\
\hline 4 & $\begin{array}{l}\text { eLearning raises the quality } \\
\text { and efficiency of learning } \\
\text { process }\end{array}$ & 2 & 1 & 3 & 40 & 34 & 4.288 & 0.8143 & 85.75 & A \\
\hline $\begin{array}{l}\text { eLearning is more } \\
\text { convenience than traditional } \\
\text { lectures, in terms of updating } \\
\text { and reusing lecturers easily }\end{array}$ & 2 & 6 & 14 & 29 & 29 & 3.963 & 1.0366 & 79.25 & A \\
\hline
\end{tabular}

As evident in table 5 above, nearly all respondents agreed about each benefit demonstrated in this questionnaire. The percentages of the respondents' agreement about each statement was quite high. Besides, the sum of the means was 21.652 and the number of the items was 5, consequently, the average for this dimension was 4.33 . This is closer to the number 4 on the five-Likert scale. Thus, the majority of participated lecturers in this study agreed about the advantages of eLearning and as it has been claimed by Roger (1995) that the willingness for new adoption depends on the relative advantages (Martins et al, 2004), this result might affect positively on the eLearning usage in the future.

\section{Conclusion}

To conclude, eLearning is one of the beneficial technology that has played an important part in education globally. Moreover, many countries have adopted eLearning in their educational organisations including universities, while others have challenges prevent adopting it. Furthermore, eLearning has brought many advantages for educational organisations, lecturers and students. Yet, it has many drawbacks and encounters a variety of challenges.

The experience of using eLearning at Zawia University has brought the chance to adopt it as a part of the education system. Additionally, this study concluded that there is an existence of some essential technologies facilitating using eLearning as the conducted survey indicated that most of the 80 participated lecturers have used eLearning using these existing technologies. However, the result of this research highlighted important challenges that affect eLearning usage. The most serious challenge was agreed by nearly all participants was about the bad internet services and electricity interruption. Another critical concern was about the cost perspective of the eLearning facilities, as some participated lecturers seemed to have financial constraints to contribute to eLearning, especially, that there are no rewards or motivations for using it. Other important eLearning challenges are the difficulty of teaching modules that require hands-on experience and the difficulty of controlling cheating during online assessments.

The success of eLearning depends on the ability and affordability of government first 
and then universities. As well, it depends on teaching staff's skills, experience, and ambition of using eLearning. Although addressing the problems facing the adoption of eLearning may need time, budget and more effort, the result would cause a huge benefit. In addition to increasing the quality of educational institutions and the efficiency of teaching staff and students, eLearning would bridge the gap created by war, political issues and diseases.

\section{Recommendation}

There are some recommendations resulted from this study and summarised in the following points:

1- The required facilities of eLearning represented in a free and good internet connection, and related software should be provided for lecturers.

2- Improve lecturer's skills of using information and communication technology, especially eLearning facilities.

3- Lecturers must be trained to combine various ways of delivery (i.e. offline, online, and blended) to efficiently facilitate lectures and to be prepared enough for online teaching when required.

4- Because of computer and internet literacy, it is highly recommended to integrate eLearning as a main subject or optional choice for all specialisation or in high school curriculum, which needs to be always up-to-date and match the requirement of education and society.

5- It is recommended to provide an Arabic version of the required programs to enable lecturers with English-understanding difficulty to use them easily.

6- It is also recommended offering rewards to motivate lecturers using eLearning.

7- E learning should integrate with traditional delivering of education because of the advantages it provides and its support to the actual learning processes.

8- Increase investments in eLearning, support it in the Libyan universities, and authorise it as a part of the teaching system or an option for students who cannot attend the actual classrooms and in special circumstances.

\section{Future Studies}

More studies could be done to investigate more aspects of eLearning in order to improve eLearning in Libya and other developing countries. For instance, identifying factors of success and failure of eLearning, discovering eLearning challenges and opportunities from students' prospects, the impact of demographic variables on eLearning usage, and investigating barriers towards eLearning adoption in broader range of educational organisations. 


\section{References}

AKBAR, M.S.U. (2005) ELearning in Developing Countries: Challenges and Opportunities, Bangladesh Perspective. In: Proceedings of the Second International Conference on eLearning for Knowledge-Based Society, Bangkok, August 2005. Thailand: The International Journal of the Computer, the Internet and Management, pp. 16.1-16.3.

AKKOYUKLU, B. and SOYLU, M.Y. (2006) A Study on Students Views On Blended Learning Environment. Turkish Online Journal of Distance Education, 7(3), pp. 43-56.

ALRUWAIS, N., WILLS, G. and WALD, M. (2018) Advantages and Challenges of Using e-Assessment. International Journal of information and Education Technology, 8(1), pp. 34-37.

ARKORFUL, V. and ABAIDOO, N. (2015) The role of e-learning, advantages and disadvantages of its adoption in higher education. International Journal of Instructional Technology and Distance Learning, 12(1), pp. 29-42.

AZZI-HUCK, K. and SHMIS, T. (2020) Managing the impact of COVID-19 on education systems around the world: How countries are preparing, coping, and planning for recovery. The World Bank group. Weblog [Online] 18th March. Available from:

https://blogs.worldbank.org/education/managing-impact-covid-19-education-systems-around-world-howcountries-are-preparing [Accessed 02/11/2020]

BATES, A.W. and BATES, T. (2005) Technology, E-learning and Distance Education. $2^{\text {nd }}$ ed. The USA and Canada: Routledge.

CLARK, R.C and MAYER, R.E (2016) E-learning and the Science of Instruction: Proven Guidelines for Consumers and Designers of Multimedia Learning. 4th ed. New Jersey: John Wiley \& Sons, Inc.

ELKINS, D. and PINDER, D. (2015) E-learning Fundamentals: A Practical Guide. The United States: The Association for Talent Development (ATD) Press.

EUROPEAN DATA PORTAL (2020) Education during COVID-19: Moving towards e-learning [WWW] The Publications Office of the European Union. Available from:

https://www.europeandataportal.eu/en/impact-studies/covid-19/education-during-covid-19-moving-towards-elearning [Accessed 21/10/2020]

GILBERT, L., WHITELOCK, D. and GALE, V. (2011) Synthesis report on assessment and feedback with technology enhancement. Technical Report, University of Southampton.

HAMEED, S., BADII, A. and CULLEN, A.J. (2008) Effective E-Learning Integration with Traditional Learning in a Blended Learning Environment. In: European and Mediterranean conference on information system, Dubai, May 2008.

HEBERLING, M. (2002) Maintaining Academic Integrity in Online Education. Online Journal of Distance Learning Administration, 5(1).

HOLMES, B. and GARDNER, J. (2006) E-Learning: Concepts and Practice. London: SAGE Publications Ltd.

HSBOLLAH, H.M. and IDRIS K.M. (2009) E-learning Adoption: the role of relative advantages, trialability and academic specialization. Emerald Group, 26(1), pp. 54-70.

KENNEDY, K. et al. (2000) Academic dishonesty and distance learning: Student and faculty views. College Student Journal, 34(2), pp. 309-314.

KHAN, H.B. (2005) Managing e learning: design, delivery, implementation and evaluation. The United States of America: Information Science Publishing-an imprint of Idea Group Inc.

KLEIN, D. and WARE, M. (2003) E-learning: new opportunities in continuing professional development. Learned publishing, 16 (1), pp. 34-46.

LI, C. and LALANI, F. (2020) The COVID-19 pandemic has changed education forever [WWW] World Economic Forum. Available from:

https://www.weforum.org/agenda/2020/04/coronavirus-education-global-covid19-online-digital-learning/

[Accessed 15/11/2020]

LIU, Y. and WANG, H. (2009) A comparative study on e-learning technologies and products: from the East to the West. Systems Research \& Behavioral Science, 26(2), pp. 191-209.

MACKEY, K. (2012) How online learning can solve teacher shortage problems. Christensen Institute. Weblog [Online] $2^{\text {nd }}$ October. Available from:

https://www.christenseninstitute.org/blog/how-online-learning-can-solve-teacher-shortage-problems/

[Accessed 28/06/2021]

MARTINS, C.B.M.J., STEIL, A.V. and TODESCO, J.L. (2004) Factors influencing the adoption of the internet as a teaching tool at foreign language schools. Computers and Education, 42(August), pp. 353-74.

MONTOYA, S. and BARBOSA, A. (2020) The Importance of Monitoring and Improving ICT Use in Education Post-Confinement. UNESCO Institute of Statistics. Weblog [Online] $15^{\text {th }}$ May. Available from: http://uis.unesco.org/en/blog/importance-monitoring-and-improving-ict-use-education-post-confinement 
[Accessed 04/11/2020]

NEDEVA, V. and DIMOVA, E. (2010) Some Advantages of E-Learning in English Language Training. Trakia Journal of Science, 8(3), pp. 21-28.

RENA, R. (2008) The Internet in Tertiary Education in Africa: Recent Trends. International Journal of Computing and ICT Research, 2(1), pp. 9-16.

ROGERS, E. (1995) Diffusion of innovation. 4th ed. New York: The Free Press.

ROSENBERG, M.J. (2001) E- Learning: Strategies for Delivering Knowledge in the Digital Age. New York: The McGraw-Hill companies, Inc.

ROSSEN, E. and HARTLEY, D. (2001) Basics of E-Learning. The United States of America: Infoline and the American Society of Training \& Development.

ROWE, N. (2004) Cheating in Online Student Assessment: Beyond Plagiarism. Online Journal of Distance Learning, 7(2), pp. 1-10.

SINGH, H. (2001) Building Effective Blended Learning Programs. Educational Technology, 43(6), pp. 51-54.

TAMM, S. (2019) Disadvantages of E-Learning [WWW] e-students.org .Available from:

https://e-student.org/disadvantages-of-e-learning/ [Accessed 04/11/2020]

TELTSCHER, S. (2020) Digital Skills Insights: Introduction. Geneva: International Telecommunication Union publications.

UNIVERSITY OF ZAWIA WEBSITE (2021) About the University [WWW] University of Zawia. Available from:

https://www.zu.edu.ly/en/university/ [Accessed 20/08/2021]

WELSH, E.T. (2003) E-learning: emerging uses, empirical results and future directions. International Journal of Training and Development, 7(4), pp. 245-258.

ZHANG, D. et al. (2004) Can E-learning Replace Classroom Learning. Communications of the ACM, 47(May), pp. 74-79. 